\title{
Research of Ecological Platform Construction of Integrative Innovation and Entrepreneurship Practice "Sunflower" Pattern in Higher Agricultural Colleges
}

\author{
Junzheng Wang ${ }^{1, \mathrm{a}}$ and Guiexue $\mathrm{Hu}^{1, \mathrm{~b}}$ \\ ${ }^{1}$ Xincheng Street 2888, Changchun, Jilin Province 130118, PR China \\ a59545966 @ qq.com, bouixue1964@126.com
}

Keywords: Higher agricultural colleges; Innovation and entrepreneurship; Integration; Practice training platform

\begin{abstract}
The new policy The general office of the state council about the construction of entrepreneurship among the innovative demonstration base of the implementation opinions promulgated the list of 28 first demonstrative base, including four universities, Tsinghua University, Shanghai Jiao Tong University, Nanjing University and Sichuan University. In this context, this article expounded the important meaning, current status and the existing main problems undertaking ecological platform construction of integrative innovation and entrepreneurship practice "Sunflower" pattern in higher agricultural colleges from the aspect of public business innovation requirement, explored the platform construction with "sunflower" ecological pattern and solved related problems within the platform construction of integrative innovation and entrepreneurship practice in higher agricultural colleges based on the actual condition of agricultural production.

Today's social and economic development is in a transition period. In the "public entrepreneurship and innovation "big trend, how to establish the integration of students' innovation and entrepreneurship practice platform in higher agricultural colleges to meet the demand of agricultural innovation ability and entrepreneurial talents' quality required by regional economic and social development has puts new requirements [1].
\end{abstract}

\section{The Significance of Constructing Integrative Innovation and Entrepreneurship Practice Platform in Higher Agricultural Colleges}

With more and more practice and exploration for innovation and entrepreneurship education in agricultural colleges, we find that the construction of integrative innovation and entrepreneurship practice platform in higher agricultural colleges is less effective [2]. The process of the platform construction has become a times requirements and also is of great importance.

First, the construction of college students' integrative innovation and entrepreneurship practice platform is needed to promote construction of innovation country.

Competition in the 21 st century is the economy and the comprehensive national strength of competition, and the independent innovation ability is the national core competitiveness for sustainable development, and is the key to improve the comprehensive national strength [3]. The 18th report of China communist party once again stressed that the development strategy to build an innovative country, which needs talents with innovative ability and entrepreneurial quality. University is the cradle of talent training [4]. In order to promote the construction of an innovative country, all colleges and universities will cultivate talents with innovative entrepreneurial competence as a strategic task and key part based on the integration platform.

Second, the construction of college students' integrative innovation and entrepreneurship practice platform is the need of "public entrepreneurship and innovation "and times development. In the 2014 summer davos BBS, prime minister li Keqiang put forward "public entrepreneurship and innovation" for the first time and emphasized that setting off a wave of public entrepreneurship and the new situation of public innovation through reform "circumstance" in the 960 square kilometers of land[5]. In such a context, we should pay more attention to the cultivation of applied and compound talents. the cause of the college graduates entrepreneurial low success rate is mainly due 
to the graduates' lack of entrepreneurial practice ability and quality. The construction of the integration platform, can solve the problem to a great extent.

Third, the construction of college students' integrative innovation and entrepreneurship practice platform is the need of college teaching idea development.

Training innovative and entrepreneurial talents is a kind of teaching idea and education mode to adapt to economic, social and national development strategy. To develop innovation entrepreneurship education, we should realize the need to further emancipate the mind, renew the idea, set up correct concept of creative talents training and promote the all-round development of improving students' quality and ability through the practice teaching system construction.

\section{Current Status and the Existing Main Problems of the Construction of College Students' Integrative Innovation and Entrepreneurship Practice Platform}

Through investigations in 34 normal universities, the innovative and entrepreneurial education has covered almost all the universities [6]. But, they are almost all elective courses, with less required courses in the employment guidance courses. Only 6 universities set a compulsory course for business, but because of a shortage of teachers, the single course is only in management, economy and other related major, without formation of curriculum system. Since there is no clear way of training target and training, lacking of practical experience of teachers as well as scientific and effective system of education directly led to less and not optimal results of education. Only 11 universities set the college students pioneer park, but hatching effect is not obvious. There are 13 universities build the innovation platform of scientific research, but undergraduates can rarely involved in the, and achievements conversion rate is low. It hardly can combine with pioneer park, integrate practical training platform and even do not meet the expectations of the country and society.

\section{Construction of Integrative Innovation and Entrepreneurship Practice "Sunflower" Pattern Platform in Higher Agricultural Colleges}

The core purpose of innovation entrepreneurship education which our country calls for is to cultivate the innovative and entrepreneurial talents, and this process of development must provide necessary conditions for their practical ability cultivation. At the same time, the conditions between should continue to getting together, promoting each other, and forming a virtuous cycle system like ecosystem.

First, integrative innovation and entrepreneurship practice "sunflower" pattern platform consist of various elements. Integrated practice training ecological platform, this system, like a "sunflower" which enjoys external nutrients (sun, rain, soil) and growing [7]. It is a symbol of many elements including universities, government, market, society, teachers and students. These elements interrelate, interact and support with each other.

In this platform system, agricultural universities as the soil of innovation entrepreneurship education plays a basic role in training innovative entrepreneurial practice; The government and the market as an external nutrient, like sunshine, provides care and support in policy formulation, financial support, public opinion direction and the transformation of scientific research project[8]. The phototropism of sunflower which indicated a startup project practice training to follow the policy and market dual orientation; Actual society, especially the agricultural production, like the rain, provide a good atmosphere for entrepreneurship and innovation requirements; As a carrier for practice training, all kinds of sunflower leaves have the effect on innovation education practice, cultivating good ideas and projects, providing "food" for faceplate; Sunflower backbone as the path, through which all kinds of innovative entrepreneurship competition and transformation of scientific research achievements will be a variety of " nutriment " transferred to faceplate. The final foothold of sunflower faceplate for college innovation entrepreneurship education is pioneer park, through which the innovative entrepreneurial talents are cultivated, pioneering enterprises set up and innovative entrepreneurship education effective. 
Second, the operation of the integrative innovation and entrepreneurship practice "sunflower" pattern platform.

The operation of the integrative innovation and entrepreneurship practice "sunflower" pattern platform is a process which various carriers cooperate with each other. The elements such as colleges, teachers, students, government, society and market influence and restrict each other. These elements can be operated by both "inside and outside loops" and "integrated communication".

Outer loop is an ecological circulation among government, market and society. Namely, the government provides funds and policy support, the market provides the guiding role for the cultivation of the innovative entrepreneurial talents and the society provides good atmosphere for innovation [9]. Innovative talents and scientific research achievements conversion as products of platform will be sent to the society and market. The circulation do facilitate the college transformation of scientific and technological achievements into real productive forces, which benefits both enterprises, colleges, teachers and students, forming a virtuous circle.

Inner loop, also the basis of colleges, is the internal link of platform. Colleges provide the basic conditions for innovation, including the professional ability, entrepreneurial environment, academic innovation and all kinds of competition. students have the foundation to exercise in the laboratory, the scientific research platform and practice base. After selection by entrepreneurship competition innovation and transformation of scientific research achievements, the good results are hatched into pioneer park. The pioneer park provide students with resources like funds, projects, team and other aspects of like training courses and support to realize the successful cultivation of entrepreneurial talents and companies finally. The process is from bottom to top on the surface, but is actual inner loop. Teachers and students can participate in the creative and entrepreneurship practice. On the one hand, these talents with entrepreneurial ability can achieve real business, on the other hand, it can drive the innovation and development of each platform, thus provide more services for innovative and entrepreneurial talents, forming a benign ecological circulation [10].

Integrated communication mainly refers to the cycle of large system, and each carrier and platform are influenced and promoted by other. Inner loop can be influenced by the whole environment and the benefit of the inner loop will be sent into the outer loop. Concrete is that the scientific and technological achievements and startups output of inner loop have to achieve benign exchange with the external enterprises' demand of new products and technology, thus realize the integration of communication. Meanwhile, with the ascension of creative talents, the core goal of innovation and entrepreneurship education will be truly realized.

\section{Acknowledgements}

[Foundation item] : This article is one of the consequences of social science research project "Relying on the pioneer park construction of college students' innovative undertaking education ecological system research", belonging to Education Department of Jilin Province (number: Jilin Educational, Scientific and Cultural Organization [2016] no. 153)

\section{References}

[1] Levine, J.NL and More land, R.L.Progress in small group research [J]. Annual Review of Psychology, 2004, 41(1).

[2] Kunkel. The Impact of Strategy and Industry Structure on New venture Performance [D]. The University of Georgia, Athens. 2003.

[3] Liang Qiaozhuan, Zhao Wenhong. Entrepreneurship [M]. Peking University press, 2007:39.

[4] Xi Shengyang. University Entrepreneurship Education in our country the concept, theory and practice of [M]. Science Press, 2008:53.

[5] Wang Shusheng. Research on entrepreneurship education [D]. doctoral dissertation of Northeast Normal University, 2007:23. 
[6] Shang Hengzhi. College students' entrepreneurship education curriculum system of [J]. education research and experiment, 2009:7.

[7] Li Sha, Wang Linxue, Kang Xiaoling. Comparison of entrepreneurship education in Colleges and universities in China and Its Enlightenment to China [J]. Journal of Xi'an Electronic and Science University (SOCIAL SCIENCE EDITION) 2009,19, (5): 126

[8] Joseph Inpet, He Wei et al. [M]. theory of economic development in Beijing: the Commercial Press, 1990

[9] Levine, J.NL and More land, R.L.Progress in small group research [J]. Annual Review of Psychology, 2004, 41(1).

[10] Kunkel. The Impact of Strategy and Industry Structure on New venture Performance [D]. The University of Georgia, Athens. 2003. 